\title{
Accuracy In Giving an Audit Opinion: Government Internal Auditors' Perspectives
}

\section{Adam ZAKARIA ${ }^{1^{*}}$, Ajeng Ratu Aisyah Citra KHUMAIRA ${ }^{2}$, Tri Hesti UTAMININGTYAS ${ }^{3}$, Unggul PURWOHEDI ${ }^{4}$, SUSI INDRIANI ${ }^{5}$}

\author{
${ }^{1}$ Accounting Department, Faculty of Economics, Jakarta State University, Jakarta, Indonesia \\ Orcid ID: 0000-0001-5996-5729, Email: adamzakaria@unj.ac.id \\ ${ }^{2}$ Accounting Department, Faculty of Economics, Jakarta State University, Jakarta, Indonesia \\ Orcid ID: 0000-0003-4871-0346, Email: ajengratuaisyah123@gmail.com \\ ${ }^{3}$ Accounting Department, Faculty of Economics, Jakarta State University, Jakarta, Indonesia \\ Orcid ID: 0000-0003-4322-0815, Email: trihesti@unj.ac.id \\ ${ }^{4}$ Accounting Department, Faculty of Economics, Jakarta State University, Jakarta, Indonesia \\ Orcid ID: 0000-0002-0955-7871, Email: upurwohedi@unj.ac.id \\ ${ }^{5}$ Accounting Department, Faculty of Economics, Jakarta State University, Jakarta, Indonesia \\ Orcid ID: 0000-0001-8458-7440, Email: sisusie.indriani@unj.ac.id \\ ${ }^{*}$ Corresponding Author
}

\section{Received: 04.06.2021 Accepted: 14.08.2021 Published: 27.10.2021 DOI: $\underline{10.47750 / Q A S / 22.184 .05}$}

\begin{abstract}
This research was conducted to identify empirical evidence regarding the perception of internal auditors on accuracy in giving an audit opinion conducted by the Supreme Audit Board of the Republic of Indonesia (Badan Pemeriksaan Keuangan/BPK) using variables such as auditor professional scepticism, the audit situation and gender. The research uses primary data obtained from the distribution of questionnaires to 82 internal auditors at five inspectorates of the Inspectorate General of the Ministry of Maritime Affairs and Fisheries Republic of Indonesia (Inspektorat Jenderal Kementerian Kelautan dan Perikanan/Itjen KKP) on the audit opinion of their annual financial audit. The research method used was multiple linear regression analysis. Based on the results obtained, auditor professional scepticism and the audit situation have a significant effect on accuracy in giving an audit opinion. Meanwhile, gender does not affect accuracy in giving an audit opinion.
\end{abstract}

Keywords: Professional Scepticism, Audit Situation, Gender, Audit Opinion.

\section{Introduction}

The planning, implementation and accountability processes related to the spending of the state budget are required to follow a regulated mechanism. Law of the Republic of Indonesia Number 17/2003 concerning State Finances requires management of the State Revenue and Expenditure Budget (Anggaran Pendapatan dan Belanja Negara/APBN)/Regional Revenue and Expenditure Budget (Anggaran Pendapatan dan Belanja Daerah/APBD) to be accountable for its implementation in the form of financial statements to the House of Representatives (Dewan Perwakilan Rakyat/DPR)/Regional House of Representatives (Dewan Perwakilan Rakyat Daerah/DPRD) after being audited by BPK no later than six months after the end of the fiscal year. Government entities, namely central and regional government (province, regency and city), in preparing their financial statements, follow the Government Accounting Standards (Standar Akuntansi Pemerintahan/SAP). An amendment of the 1945 Constitution explains that the President serves as both the head of state as well as the head of government in the Presidential Institution. In
Indonesia, executive agencies consist of the President, Vice President and Ministries/Institution (Kementerian/Lembaga/ $\mathrm{K} / \mathrm{L}$ ) while BPK, as a free and independent state institution, is tasked with auditing the management and accountability of state finances.

The BPK audits the management and accountability of the state finances in accordance with Law of Republic Indonesia Number 15/2004 concerning Audit of State Management and Responsibility. As part of its audit, BPK publishes an audit report (Laporan Hasil Pemeriksaan/LHP) that includes an audit opinion in the form of an auditor professional statement related to whether the information contained within the financial statements is presented fairly in all material aspects. Auditors conduct tests and assessments on the implementation of the Government Internal Control System (Sistem Pengendalian Internal Pemerintah/SPIP), which in this case includes the $\mathrm{K} / \mathrm{L}$ of the central and regional government (province, regency and city). Following publication of the audit report, these entities are required to follow up on the recommendations as stated in the LHP no more than 60 days after receipt of the LHP. The provision of an audit opinion that reflects the data and facts collected and evaluated during the audit process assists BPK 
auditors in encouraging government entities to improve the management of state finances via constructive recommendations and is useful for correcting any weaknesses found. It also facilitates the monitoring of recommendations given in the LHP.

To support their audit assignments, BPK has compiled and implemented audit standard guidelines in the form of Government Audit Standards 1995, Supreme Audit Board Regulation Number 1/2007 concerning State Financial Audit Standards (Standard Pemeriksaan Keuangan Negara/SPKN), which were subsequently updated with the issuance of BPK Regulation Number 1/2017. SPKN is applied in all audit assignments for all government entities, programmes, activities and functions related to the implementation of state financial management and responsibility for the purpose of obtaining sufficient and appropriate audit evidence as the basis for providing an audit opinion. In evaluating whether the financial statements audited are presented fairly by government entities, the auditors examine their accordance with SAP. The purpose of SAP, as explained in the conceptual framework, is as a reference for standard setters, those charged with preparing financial statements, examiners in providing an audit opinion, and the users of financial statements when interpreting the information presented. The standards have been continuously updated since the first issuance of SAP, Government Regulation of Republic of Indonesia Number 24/2005 concerning Government Accounting Standards, later updated by Government Regulation Number $71 / 2010$ related to the accrual basis in a government accounting system. The most recent SAP is the 2019 version.

The LHP for the 2019 Indonesian central government audited financial statements (Laporan Keuangan Pemerintah Pusat/LKPP) contains the audit opinions for all K/L for the previous five years (2015-2019). Almost all entities received unqualified (Wajar Tanpa Pengecualian/WTP) audit opinions. A press release from the BPK Public Relations and International Cooperation Bureau, published on 14 July 2020, explained that out of a total of $87 \mathrm{~K} / \mathrm{L}$ in $2019,84 \mathrm{~K} / \mathrm{L}$ financial statements received WTP opinions. This was an improvement on the result from 2018, the LHP for which contained 81 WTP opinions. SPKN in Audit Standard Statement 300 on Audit Reporting Standards forms the basis for providing an audit opinion of government entities. Meanwhile, private companies/nongovernment entities refer to Public Accountant Professional Standards (Standar Profesional Akuntan Publik/ SPAP) Audit Standard (Standar Audit/SA) Numbers 700, 705, 706 and 710, as compiled by the Indonesian Institute of Certified Public Accountants (2017).

From the perspective of internal auditors, Government Regulation Number 60/2008 Republic of Indonesia explains that, concerning SPIP, the internal control system is carried out comprehensively within the central government and local government by the Development and Financial Supervisory Board (Badan Pengawas Keuangan dan Pembangunan/BPKP), Inspectorate General and Provincial/Regency/City Inspectorate. SPIP comprises the control environment, control activities, information and communication, and internal control monitoring. SPIP aims to provide adequate assurance in achieving the objectives of state governance, the reliability of financial statements, safeguarding of assets and compliance with laws and regulations. Other regulations governing the role of the inspectorate are explained in Government Regulation of the Republic of Indonesia Number 18/2016 concerning Regional Apparatus, wherein Provincial/Regency/City Inspectorates are the supervisory elements concerning the implementation of regional government. Furthermore, certain elements of this regulation were updated in Number 72/2019 concerning Regional Apparatus. The functions of regional inspectorates include formulating technical policies for supervision of the operational and financial performances through audit, review, evaluation and monitoring; coordination with respect to the prevention of corruption; and supervising the implementation of the bureaucratic reform programme.

Previous research regarding accuracy in providing an audit opinion has mostly been conducted by private sector auditors who practise in public accounting firms. With 87 government entities classed as K/L as well as 34 provinces, along with 514 regencies/cities, the scope of government entities is very large. The factors that influence accuracy in providing an audit opinion include the following: 1). Auditor professional scepticism (Lubis, 2015; Suryani, 2017; Widiarini and Suputra, 2017; Winadi and Mertha, 2017; Pelu et al., 2018; Wirasari et al., 2019; Akmala, 2020; Kamil and Fathonah, 2020), 2). Independence (Sari, 2017; Winadi and Mertha, 2017; Kamil and Fathonah, 2020), 3) Audit situation (Suraidah et al., 2005; Gusti and Ali, 2008; Kushasyandita and Januarti, 2012; Nur and Wahyudi, 2014 Sutrisno and Fajarwati, 2014; Sari, 2017; Pelu et al., 2018), 4). Professional ethics (Suraida, 2005; Kushasyandita and Januarti, 2012; Sutrisno and Fajarwati, 2014; Lubis, 2015 Suryani, 2017; Widiarini and Suputra, 2017; Winadi and Mertha, 2017; Pelu et al., 2018; Wirasari et al., 2019), 5). Audit expertise (Kushasyandita and Januarti, 2012; Sutrisno and Fajarwati, 2014; Suryani, 2017; Widiarini and Suputra, 2017; Pelu et al., 2018; Hermawan and Wulandari, 2019; Wirasari et al., 2019), 6). Auditor's professional commitment (Lubis, 2015; Widiarini and Suputra, 2017; Wirasari et al., 2019), 7). Experience (Kushasyandita and Januarti, 2012; Sutrisno and Fajarwati, 2014; Lubis, 2015; Pelu et al., 2018), 8). Gender (Kushasyandita and Januarti, 2012; Sutrisno and Fajarwati, 2014; Lubis, 2015; Winadi and Mertha, 2017), 9). Audit risk (Suraida, 2005; Lubis, 2015), 10). Work pressure (Lubis, 2015), 11). Audit environment (Suryani, 2017), 12). Integrity (Kamil and Fathonah, 2020), 13). Professionalism (Kamil and Fathonah, 2020), and 14). Auditor competence (Suraida, 2005).

In relation to audit engagement, each auditor must bear their professional scepticism in mind; for example, in terms of collecting audit evidence through documentation, interviews, physical examination, reviewing internal controls, etc. Auditors are required to take into account the existence of audit risk so that any immaterial misstatement can be accepted. Furthermore, reasonable assurance on the risks that exist and the audit evidence obtained as a result forms the basis for issuing an audit opinion. Previous studies such as Pelu et al. (2018) have found that professional scepticism influences accuracy in giving an audit opinion. However, other research has concluded differently, namely Wirasari et al. (2019), who found that auditor professional scepticism has a negative effect on accuracy in providing an audit opinion. Meanwhile, auditors may encounter various situations during an audit assignment. Different audit procedures may be applied depending on the characteristics of the auditee industry and the associated risks. For this reason, auditors must adjust the appropriate audit procedures so that the risks encountered can be managed. Therefore, the audit opinion issued is in accordance with the results of an evaluation of the existing audit evidence. The audit situation has been shown to have an influence on accuracy in giving an audit opinion (Pelu et al., 2018). However, this is contrary to Sari's (2017) research, which concluded that the audit situation does not have a significant effect on accuracy in giving an audit opinion. In various fields, the issue of gender equality has led to increased pressure for men and women to occupy certain positions and have the same opportunities. This is also marked by the acceptance of all genders in schools and universities around the world, meaning there are fewer singlesex schools nowadays. This accords with a research finding from Winadi and Mertha (2017) that shows gender has no effect on accuracy in giving an audit opinion, whereas Kushasyandita and Januarti (2012) found inversely. 
This study aims to examine the perceptions of internal auditors at Itjen KKP using three independent variables, namely professional scepticism, audit situation and gender, which influence the accuracy of BPK auditors in giving an audit opinion.

\section{Literature Review}

\subsection{Cognitive Dissonance Theory}

According to Festinger (1957), cognitive dissonance theory is a gap between two inconsistent cognitive elements that causes psychological discomfort. Cognitive elements can take the form of knowledge, opinions or other things that people believe about the environment, themselves or their behaviour. Humans prefer beliefs/ideas over inconsistencies/conflicts, so they attempt to reduce/eliminate the latter by altering their perceptions. This encourages humans to find ways to resolve such inconsistencies. In this research context, cognitive dissonance theory is used to explain the influence of the interaction between factors such as professional scepticism, audit situation and gender on accuracy in giving an audit opinion. In practice, cognitive dissonance arises when professional scepticism is not maintained or is at a low level when collecting appropriate and sufficient audit evidence, meaning that the auditor is not critical or easily accepts client explanations. An audit team that is unable to anticipate/reduce the uncertainty/audit risk faced will fail to plan and implement the relevant audit procedures to reflect the client's actual conditions. Meanwhile, cognitive gaps/dissonance can also occur between male and female auditors with regard to their mindset when reducing gaps/inconsistencies during an audit assignment. Thus, these three factors will influence the level of accuracy in giving an audit opinion on the client financial statements.

\subsection{Auditing}

This study relates to the perception of government internal auditors of the BPK auditors' opinion; as such, it is necessary to first explain the relevant definitions. Auditing is the accumulation and evaluation of evidence on information for the purpose of determining and reporting on the degree of correspondence between the information being audited and established criteria (Arens et al., 2017). According to SPKN (2017), an audit is a process of problem identification, analysis and evaluation that is carried out independently, objectively and professionally based on auditing standards, to assess the truth, accuracy, credibility and reliability of information regarding the management and responsibility of state finances. During the audit assignment, SPKN is used as a guideline for BPK auditors, public accountants carrying out the audit of state finances, and Government Internal Supervisory Apparatus (Aparatur Pengawasan Internal Pemerintah/APIP). APIP is charged with supervising, within the scope of its authority, in organisational units within $\mathrm{K} / \mathrm{L}$ of the central and regional government (province, regency and city). The APIP assigned to the Inspectorate General of the Ministry is responsible to the relevant Minister for the programme supervision. In conducting it, the Inspectorate General's functions include formulating technical policies for internal control, supervising performance and finance, reviewing and monitoring special supervision, and preparing supervisory reporting.

Internal audits are conducted in various organisations with different objectives, sizes, complexities and structures. This requires standard guidelines as support materials that can be used as a reference when carrying out internal audit procedures; in this case, these are the International Standards for Professional Practice of Internal Auditing from the Institute of
Internal Auditors (IIA, 2016). For corporate success and longevity, it is very important to manage good governance, risk management and internal controls. The internal auditor plays a role in helping senior management and governing bodies such as the board of directors, audit committee and government entities to fulfil their responsibility to achieve corporate goals. Internal auditing is an independent, objective assurance and consulting activity designed to add value and improve an organisation's operations. It helps an organisation accomplish its objectives by bringing a systematic, disciplined approach to evaluating and improving the effectiveness of risk management, control and governance processes (IIA 2015, Lenz and Hahn, 2015). In supporting the internal auditor's role, it is important to maintain and update their competence. The result identified internal auditor competence as a determinant of internal audit effectiveness in the public sector (Adam et al., 2020).

\subsection{Audit opinion}

The audit report is the final stage of the entire audit process that assesses the fairness of financial statements based on financial accounting standards. The report is extremely important as it constitutes the means by which the audit assignment will communicate its findings based on its evaluation of the audit evidence. Users of financial statements such as shareholders, government entities etc. rely on the results of audit reports for accountability of financial management and its presentation on financial statements (Arens et al., 2017). The categories of an audit opinion include unqualified opinion (Wajar Tanpa Pengecualian/WTP), qualified opinion (Wajar Dengan Pengecualian/WDP), adverse opinion (Tidak Wajar/TW) and disclaimer opinion (Tidak Menyatakan Pendapat/TMP). For government entities, the reporting guidelines refer to Auditing Standards Statement 300 concerning Audit Reporting Standards, which regulates the obligation of government auditors to prepare an audit report in the areas of financial audit, performance audit and audit for a specific purpose (SPKN, 2017). For the private sector, the formulation of an audit opinion is based on Audit Standards 700, 705, 706 and 710 (IAPI, 2017). An example of an audit opinion for a government entity is a financial audit of the KKP for the period 2015-2019, where the audit opinions issued are WTP, TMP, TMP, WTP and WTP respectively.

\subsection{Internal Auditor Perception}

Both internal and external government auditors have the same responsibility and work together in carrying out their duties and functions related to the supervision of state finance. Internal auditors certainly hope that there is a common perception regarding the audit procedures, evidence and opinion issued by external auditors. The perceptions of Itjen KKP internal auditors are based on their perception of the BPK audit opinion, the attitude of the external auditors and the situation during an audit of annual financial statements. SPKN stipulates the same perception for both parties in terms of the similarity of guidelines for the implementation of audit procedures. However, in reality, during audit fieldwork, different perceptions may arise due to differences in the interpretation of the audit evidence, risks, scope and content within the government financial statements. Furthermore, internal auditors have a new control mechanism within the Itjen KKP Regulation Number 115/PER-ITJEN/2020 concerning Guidelines for Supervision of the Itjen KKP in the planning, preparation and implementation of audit; review, evaluation and monitoring of programmes and activities; and monitoring and reporting of the supervision results. According to Robbins (2015), perception is a process in which an individual organises and interprets the impressions that their senses discern in order to give meaning to their environment. However, 
an individual's perception may differ from the actual reality. According to the Indonesian dictionary, perception is a response to the direct acceptance of something or the process of someone knowing things through their five senses.

\subsection{Auditor Professional Scepticism}

Auditor standards require that an audit assignment must be well planned in order to provide sufficient assurance in detecting material error and fraud in the financial statements. This can be achieved by maintaining a mental attitude of professional scepticism in all matters related to the assignment (Arens et al., 2017). The aim of maintaining scepticism during an assignment concerns anticipating the possibility of fraud in terms of ensuring the reliability of audit evidence and seeking answers to important questions related to documents (Tuanakotta, 2017). Scepticism comprises two aspects: a questioning mind and a critical assessment of the audit evidence that enables the auditor to draw appropriate conclusions and not easily believe the content of the audit evidence submitted by the client in the form of documents, answers, calculations, etc. For this reason, auditors must employ comparative knowledge and calculations during their discussion with clients, in addition to possessing good communication skills. Auditor professional scepticism is also explained in the SPKN for Audit Standard 100 concerning General Standards. This is used during an audit assignment to assess the obtained reliable documents and responses to inquiries, identify indications of fraud and develop additional procedures as needed. While the client is responsible for corporate governance with the implementation of honesty and integrity, the auditor must maintain his professional scepticism in collecting audit evidence with sufficient assurance, as outlined in Audit Standard 200 (IAPI, 2017).

Various previous studies have considered auditor professional scepticism, with most demonstrating a significant and positive effect of professional scepticism on accuracy in giving an audit opinion (Suryani, 2017; Widiarini and Suputra, 2017; Winadi and Mertha, 2017; Pelu et al., 2018; Akmala, 2020). Meanwhile, other studies have produced conflicting conclusions (Wirasari et al., 2019; Kamil and Fathonah, 2020). Professional scepticism as a moderating variable has been shown to strengthen the effect of independent variables such as competence and audit situation on accuracy in giving an audit opinion, while this was not found with other moderating variables, namely the relationship between ethics and pressure on the appropriateness in giving an audit opinion (Lubis, 2015).

\subsection{Audit Situation}

During audit assignments, auditors face situations in which they must accept a certain level of risk/uncertainty. This includes in accurate audit evidence, ineffective internal control and the fair presentation of financial statements, which must be evaluated up to the issuance of the audit report. Therefore, in a bid to overcome the above problem, auditors perform audit procedures to obtain an understanding of the client's industry and its environment, including the internal control, and assess the risk of material misstatement of the client's financial statements; achieving this requires good auditor communication skills. Moreover, it is necessary to be able to understand the audit situation so that it can be properly managed until the audit team has completed a high-quality audit. This includes, for example, conducting a risk assessment using professional judgement. The risk assessment employs an audit risk model that is used to determine the planned detection risk (PDR) level, which in turn is influenced by the level of acceptable audit risk (AAR), inherent risk (IR) and control risk (CR) (Arens et al., 2017). The IAPI has guidance for auditors in dealing with uncertain audit situations and issues relevant audit standards, including SA 315 concerning the Identification and Assessment of Risks of Misstatement through Understanding the Entity and its Environment. Risk assessment procedures include enquiries to the client's management and human resources department regarding material misstatement due to error or fraud, and analytical procedure. Auditors should face no uncertainty regarding the audit situation and must have confidence in issuing an audit opinion on financial statements.

The conceptual framework for the SPKN audit explains matters related to risk management during the assignment. Audit risk is the risk that the result of an audit assignment does not match the actual conditions. An uncertain audit situation will encourage auditors to develop audit procedures and carry these out for the purpose of reducing the audit risk. The auditor must therefore be aware of, consider and manage audit risk. To support the implementation of all of the audit procedures, an efficient and effective communication strategy should be developed, both within the audit team and to the client, for example in terms of obtaining data and information during the collection of audit evidence, and submitting the audit report to the general meeting of stockholders. Auditors sometimes also face audit situations where there is doubt as to whether an action is allowed or not. Compliance with the Code of Ethics of Professional Public Accountants (IAPI) will help to reduce this uncertainty faced by auditors and reduce potential differences in views with clients. Basic principles of ethics govern the mandatory characteristics that auditors must possess, namely integrity, objectivity, competence, professional prudence, confidentiality and professional behaviour. Direct interactions between auditors and clients during the audit assignment also contribute to a potentially uncertain audit situation. Therefore, compliance with the following matters can help to mitigate any rise in differences in view regarding professional ethics, such as conflict of interest in financial and family matters, gifts and partner rotation.

Prior research has been conducted on the issue of the audit situation as a determinant of accuracy in giving an audit opinion. Suraida et al. (2005) and Pelu et al. (2018) found a significant relationship between the audit situation and accuracy in giving an audit opinion. Gusti and Ali (2008) reached the same conclusion, whereby the audit situation supports the quality audit process, which is reflected in the issuance of an appropriate audit opinion. Various other previous studies (Kushasyandita and Januarti, 2012; Sutrisno and Fajarwati, 2014) also found that the audit situation has a positive effect on accuracy in giving an audit opinion through professional scepticism. Inversely, however, Sari (2012), Nur and Wahyudi (2014) and Sutrisno and Fajarwati (2014) found that the audit situation had no effect on accuracy in giving an audit opinion.

\subsection{Gender}

While the issue of gender remains a matter of public concern, in the past there were differences in gender requirements for continuing studies at the undergraduate level, specifically for men at Ivy League universities in the USA. As a result, women's colleges were established; nowadays, however, such gender policies have been abolished, meaning men and women have access to the same opportunities. In Indonesia, the spirit of equality continues, with quotas for the number of women in parliament and state-owned enterprises. Naturally, however, the family factor becomes an obstacle for women in pursuing a career in public accounting firms (Kantor Akuntan Publik/KAP), thus making it very rare for women to occupy the highest positions as partners in KAP. However, middle to lower positions are often occupied by both genders. According to Tuanakotta (2011), compared to men, women have advantages in terms of reading non-verbal cues such as eye contact, facial expressions, emotions, posture, etc. The 
difference in reactions between men and women can also be seen in their emotional responses and the ability to read other people's characters. In this case, women tend to display more emotions to a greater degree than men, both positive and negative ones, except for anger.

Differences in attitudes and mindsets between men and women can be found within a team of auditors giving an audit opinion. This is supported by Kushasyandita and Januarti (2012), who found that gender has a direct effect on accuracy in providing an audit opinion on financial statements. Similar results were obtained by Lubis (2015), either directly or indirectly, with the professional scepticism of auditors as a moderating variable that mediates the relationship between gender and accuracy in giving an audit opinion. Other studies, however, have reached different conclusions. Winadi and Mertha (2017) concluded that gender does not have a significant effect on accuracy in giving an audit opinion as currently, the business of auditing is mostly carried out by women as opposed to men. The same results were reflected in the research of Sutrisno and Fajarwati (2014), both directly and indirectly through an intervening variable, namely the auditor's professional scepticism.

\subsection{Hypotheses Development}

Auditors must maintain professional scepticism during an audit assignment and anticipate the possibility of fraud resulting in a material misstatement of the client's financial statements. Professional scepticism will provide sufficient assurance on all audit evidence requested from the client that then forms the basis for auditors to express an audit opinion. Previous research has delivered mixed results in terms of using independent variables with a view to statistically testing their potential effect on audit opinion, and this is interesting to prove in this study context. Significant and positive conclusions have been obtained by Suryani (2017), Widiarini and Suputra (2017), Winadi and Mertha (2017), Pelu et al. (2018) and Akmala (2020). Meanwhile, other studies found differently, including Lubis (2015), Wirasari et al. (2019) and Kamil and Fathonah (2020).

$\mathrm{H} 1$ : Auditor professional scepticism affects the accuracy in giving an audit opinion.
The uncertainty of the situation facing the auditor during an audit assignment can raise doubts; to this end, it needs to be anticipated by carrying out a risk assessment and implementing sound audit planning and procedures. The audit team must have sufficient confidence in giving an audit opinion that reflects the actual condition of the client's financial statements. This risk/uncertainty can be reduced by improving communication between the audit team and client, which in turn can reduce the potential different views between them. Compliance with professional ethics also protects auditors from the potential for conflicts of interest that could lead to a more uncertain audit situation. Previous research regarding the effect of the audit situation on the accuracy of an audit opinion has yielded mixed conclusions. Suraida et al. (2005), Gusti and Ali (2008), Kushasyandita and Januarti (2012), Sutrisno and Fajarwati (2014) and Pelu et al. (2018) found that the audit situation has a significant influence on accuracy in giving an audit opinion, either directly or indirectly, through professional scepticism. That result contradicts the conclusions of Sari (2012), Nur and Wahyudi (2014) and Sutrisno and Fajarwati (2014), who found that the audit situation had no effect on accuracy in giving an audit opinion.

$\mathrm{H} 2$ : The audit situation affects the accuracy in giving an audit opinion.

Gender equality in various opportunities continues to be demonstrated through expanding access to education, political representation, the highest positions in companies, etc., with the aim of ensuring the widest possible equal opportunities for men and women. Both genders have different characteristics, which can be seen in their emotional reactions, facial expressions, eye contact, emotions, etc. This study aims to examine the extent to which differences in internal auditors' perceptions in terms of seeing gender serve as a determining factor for accuracy in giving an audit opinion on financial statements. Kushasyandita and Januarti (2012) and Lubis (2015) concluded that gender has a direct or indirect effect on accuracy in giving an audit opinion. Inversely, Winadi and Mertha (2017) and Sutrisno and Fajarwati (2014) found that gender has no effect on accuracy in giving an audit opinion, either directly or indirectly.

H3: Gender affects the accuracy in giving an audit opinion.

The research framework is outlined as follows:

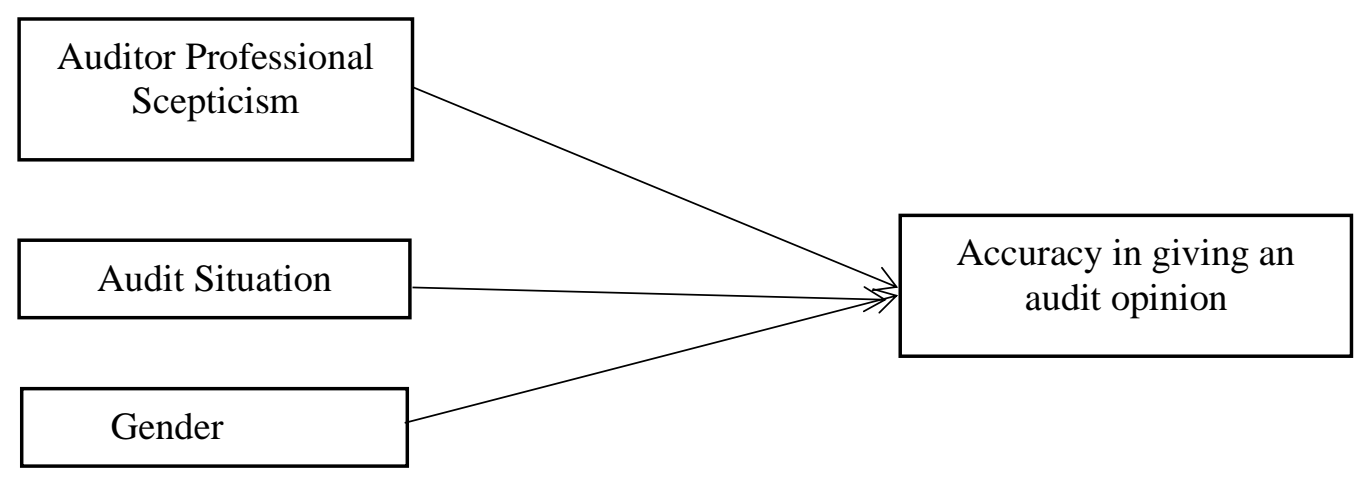

Figure 1: Research Framework

\section{Research Method}

$\mathrm{KKP}$ is one of the $\mathrm{K} / \mathrm{L}$ within the central government structures and has 82 internal auditors who served as respondents in completing the distributed questionnaires. Previously, this study conducted a data quality test among 25 internal auditors at the Inspectorate General of the Ministry of Agriculture in order to check the validity and reliability of the statements within the questionnaires. The regulation underpinning the activities of the Itjen KKP internal auditors begins with Presidential Decree Number 136/1999 concerning Position, Duties, Organisational Structure, Departments' Work Procedures within the Indonesian central government. The latest regulation was updated with the enactment of KKP Regulation Number 6/PERMEN-KP/2017 concerning The Organisation and Work Procedures of the KKP with the task of carrying out internal supervision within the KKP environment. It 


\section{GENERAL MANAGEMENT}

encompasses functions including formulating technical policies for internal control, implementing supervision for various audit types and preparing supervisory reports. These two data collections were conducted in March - December 2020.

The perception of government internal auditors of the BPK auditors' opinion of the KKP annual financial statements audit is measured using three variables as highlighted in the research framework, using multiple linear regressions. This study applied purposive sampling to the data collection; respondents were required to have at least one year's experience working on audit assignments. Table 1 contains the data distribution relating to the 82 respondents from the main internal auditors at Itjen KKP:

\begin{tabular}{|c|l|c|c|c|}
\hline No & Inspectorate & Distributed & Processed & Percentage \\
\hline 1 & Inspectorate I & 20 & 18 & 90 \\
\hline 2 & Inspectorate II & 23 & 20 & 87 \\
\hline 3 & Inspectorate III & 22 & 15 & 68 \\
\hline 4 & Inspectorate IV & 18 & 13 & 72 \\
\hline 5 & Inspectorate V & 20 & 16 & 80 \\
\hline & & 103 & 82 & 79.6 \\
\hline
\end{tabular}

Table 1: Respondents' Data Distribution

\section{Results}

This study began by conducting a descriptive test and data quality test using 25 respondents from other ministries who served as internal auditors at the Itjen Ministry of Agriculture. This was designed to assess the validity and reliability of the three independent variables used, namely auditor professional scepticism (X1), audit situation (X2) and gender (X3) on accuracy in giving an audit opinion. The result of the descriptive analysis test indicates that the mean or average value is greater than the standard deviation value, which means that the average value describes the data as a whole and is homogeneous. The data quality test took the form of a test questionnaire to determine whether the statements it contained were valid and reliable. The value of the Pearson correlation for the validity test exceeded the $r$ table value, indicating that the statements in the questionnaires could be considered valid. For variables $\mathrm{X} 1$ and $\mathrm{X} 2,16$ and 15 statements respectively were submitted to the respondents. The result indicated an invalid statement for each of these variables that could therefore not be included in the actual questionnaires distributed to the Itjen KKP internal auditors. Meanwhile, for the X3 variable, all 18 statements were found to be valid. Moreover, in the reliability test, all the variables obtained a reliable Cronbach's alpha value.

Classical assumption tests were performed next, consisting of normality, multicollinearity and heteroscedasticity tests. The result of the normality test, as conducted using the KolmogorovSmirnov test, shows a significance value greater than 5\%, which means that the data used is normally distributed. In the multicollinearity test, the variance inflation factor (VIF) value of the three independent variables was between the values $>0.10$ and $<0.10$, from which it could be concluded that there was no correlation between the independent variables/multicollinearity did not occur. Finally, the heteroscedasticity test produced a significance value above $5 \%$ for the three independent variables, thus indicating that the regression model is free from heteroscedasticity.

Moreover, descriptive statistical tests were conducted on the data of the 82 Itjen KKP internal auditors, including a descriptive analysis test, data quality test, classical assumption test and hypothesis testing. Each statistical result was then interpreted to provide meaning for this study. Table 2 contains the respondent characteristics including gender, age, most recent education, and length of work experience as an internal auditor at Itjen KKP.

\begin{tabular}{|l|l|c|c|}
\hline $\begin{array}{c}\text { Respondent } \\
\text { Characteristic }\end{array}$ & \multicolumn{1}{|c|}{ Description } & Number & Percentage \\
\hline \multirow{3}{*}{ Gender } & Men & 53 & 65 \\
\cline { 2 - 4 } & Women & 29 & 35 \\
\hline \multirow{4}{*}{ Age } & $26-35$ & 17 & 21 \\
\cline { 2 - 4 } & $36-40$ & 25 & 30 \\
\cline { 2 - 4 } & $41-45$ & 16 & 20 \\
\cline { 2 - 4 } & $>46$ & 24 & 29 \\
\hline \multirow{4}{*}{ Education } & Undergraduate & 42 & 51 \\
\cline { 2 - 4 } & Master & 40 & 49 \\
\cline { 2 - 4 } & Doctoral & 0 & 0 \\
\hline \multirow{4}{*}{ Work Experience } & $1-5$ years & 8 & 10 \\
\cline { 2 - 4 } & $6-10$ years & 18 & 34 \\
\cline { 2 - 4 } & $11-15$ years & 28 & 34 \\
\cline { 2 - 4 } & $>15$ years & 28 & 34 \\
\hline
\end{tabular}

Table 2: Respondent Description 
Male respondents dominated by $65 \%$ compared to women. The researchers suspect that this imbalance can be attributed to the characteristics of the KKP ministry, which demands a high degree of mobility during audit assignments. Their perspective in interpreting the work of BPK auditors in the form of an audit opinion on financial statements is of concern here. Next, the 3640 age range was the largest among these respondents, indicating that the transition from young towards older ages is more dominant than other age ranges. The level of undergraduate education of the respondents was $51 \%$, indicating the background of the technical needs of accounting and auditing, compared to the background of the respondents at the master level, which stood at $49 \%$. Furthermore, the length of the respondents' work experience was dominated by auditors who had worked for more than 11 years, accounting for $68 \%$, from which it can be seen that the majority were highly experienced auditors.

Table 3 describes the results of the multiple liner regression analysis on the prediction model, with the equation obtained as follows:

$A G A O=20.755+0.493 S P+0.495 S-0.651 G+\varepsilon$

Where:

AGAO = Accuracy in giving an audit opinion

PS = Professional Scepticism

AS = Audit Situation

$\mathrm{G} \quad=$ Gender

a $\quad=$ Constant $\mathrm{a}$

\begin{tabular}{|c|c|c|c|c|c|c|}
\hline & & \multicolumn{2}{|c|}{$\begin{array}{l}\text { Unstandardised } \\
\text { Coefficients }\end{array}$} & \multirow{2}{*}{$\begin{array}{c}\begin{array}{c}\text { Standardised } \\
\text { Coefficients }\end{array} \\
\text { Beta } \\
\end{array}$} & \multirow[t]{2}{*}{$\mathrm{T}$} & \multirow[t]{2}{*}{ Sig. } \\
\hline \multicolumn{2}{|c|}{ Model } & B & Std. Error & & & \\
\hline \multirow[t]{4}{*}{1} & (Constant) & 20.755 & 9.203 & & 2.255 & 0.027 \\
\hline & $\begin{array}{l}\text { Professional } \\
\text { Scepticism }\end{array}$ & 0.493 & 0.145 & 0.313 & 3.400 & 0.001 \\
\hline & Audit Situation & 0.495 & 0.094 & 0.487 & 5.252 & 0.000 \\
\hline & Gender & -0.651 & 0.986 & -0.056 & -0.660 & 0.511 \\
\hline
\end{tabular}

a. Dependent Variable: Accuracy in giving an audit opinion

Table 3: Multiple Regression Analysis

\section{Discussion}

The test results demonstrate significant values for the independent variables tested and it is therefore concluded that auditor professional scepticism and audit situation are both significant, while gender is not significant at the $0.05 \%$ level. The study also produced significant $F$ test results, meaning all independent variables had a simultaneous effect on accuracy in giving an audit opinion as a predictor of this research model. Furthermore, the adjusted R2 value of 0.440 indicates the strong influence of auditor professional scepticism, audit situation and gender in predicting accuracy in giving an audit opinion, corresponding to a percentage value of $44 \%$.

This paragraph explains the first hypothesis. The statistical results in Table 3 indicate that professional scepticism has a significant and positive effect on accuracy in giving an audit opinion. This shows that the Itjen KKP internal auditors hold the perception that the higher the professional scepticism of the BPK auditors, the more accurate the audit opinion issued. As such, BPK auditors maintain a critical attitude and question the veracity of all audit evidence in various forms such as physical examinations, interviews, confirmations, analytical procedures, etc. Then, they draw a conclusion as to whether the evaluated audit evidence is appropriate and adequate in terms of whether the financial statements presented fairly. Thus, during an audit assignment, auditors must have sufficient confidence that the audit opinion being expressed reflects the reality. Auditor professional scepticism is in accordance with SPKN in Audit Standard Statement 100 concerning general standards, which explains the importance of maintaining this attitude during an audit assignment so that convincing evidence is obtained. Furthermore, it becomes increasingly important to maintain professional scepticism if indications of fraud are found, which indicates the need to develop additional audit procedures. This condition is no different from the practice of cognitive dissonance in which the Itjen KKP internal auditor's perceptions of BPK auditors should not deter them from maintaining a critical attitude as they collect audit evidence and should not affect the accuracy in giving an audit opinion. This result is in line with several previous studies which concluded that auditor professional scepticism affects the accuracy in giving an audit opinion, namely Suryani (2017), Widiarini and Suputra (2017), Winadi and Mertha (2017), Pelu et al. (2018) and Akmala (2020).

This paragraph explains the second hypothesis. Table 3 indicates that the audit situation has a positive effect on the accuracy in giving audit an audit opinion. This shows that the Itjen KKP internal auditors perceive that the BPK auditors can handle the audit situation during the assignment, so that the audit opinion issued is appropriate. Many aspects can give rise to a range of different audit situations, such as the client expecting to receive a WTP audit opinion, different audit risks due to client characteristics, and professional ethics. BPK auditors are not affected by the pressures in that situation and can still provide the right audit opinion. Furthermore, auditors have a deep understanding of the client's industry characteristics and its environment, along with effective internal control that affects the reliability and fairness of financial statements. Auditors are also able to effectively plan their audit assignments so as to manage and respond well to the uncertainty/risk that they encounter within the audit situation so that it does not become a source of significant differences in view. Effective and efficient communication, both within the audit team and with the client, is very helpful in resolving the uncertainty of the audit situation at hand. In the end, auditors can build sufficient confidence as the basis for issuing the appropriate audit opinion. Regarding the cognitive dissonance theory, this study proves that the internal auditors' perception of 
the BPK auditor assignment is contradictory. The audit team is able to properly prepare an audit plan that enables it to reduce/anticipate uncertainty. The result of this study is in line with previous research which concluded that the audit situation affects the accuracy in giving an audit opinion (Suraida et al., 2005, Pelu et al., 2018; Gusti and Ali, 2008).

This paragraph explains the third hypothesis. The statistical result in Table 3 shows that gender does not have a significant effect on accuracy in giving an audit opinion. Itjen KKP internal auditors have the perception that BPK auditors, male or female, perform the audit task in accordance with SPKN and professional ethics, so that gender does not affect the accuracy in giving an audit opinion. Cognitive dissonance theory helps to explain this matter. Cognitive dissonance in the form of different mindsets between male and female auditors can be addressed through education and training so that the same audit procedures are conducted by every auditor, regardless of their gender. Several aspects also support the absence of differences in perceptions on the accuracy in giving an audit opinion, namely the fact that the number of males and females is relatively balanced. Moreover, the existing salary structure and performance allowance policy ensure equal treatment for all auditors regardless of gender, meaning the response to job responsibilities is evenly distributed. This means that differences in perceptions of audit assignment based on the gender of auditors are not proven in this study. The result obtained in this study is in line with previous studies, namely Winadi and Mertha (2017) and Sutrisno and Fajarwati (2014), which concluded that gender has no effect on accuracy in giving an audit opinion.

\section{Conclusion and Recommendation}

It can be concluded from this study that, according to the perception of the Itjen KKP internal auditors regarding the accuracy of the audit opinion on annual financial statements provided by BPK auditors, it is found that two of the three independent variables, namely auditor professional scepticism and audit situation, have a significant effect, while the third variable, gender, does not have a significant effect. This research is highly likely to be representative of all government internal auditors because BPK auditors perform standard audit procedures in accordance with SPKN. As such, individual aspects that may affect the occurrence of bias are reduced.

However, further study can be conducted in other government entities within different areas and cultures in Indonesia, which may yield different results. To support this, if we look at the 2019 audited LKPP, not all government entities were given the same audit opinion. In the last three years, the majority received WTP audit opinions, while others received WDP, TW and TMP opinions. Further research may also seek to add other independent variables from broader perspectives, namely auditor characteristics (independence, expertise and experience), the audit quality control system, professional ethics, audit procedures, etc.

\section{References}

[1] Akmala, RH., (2020). The influence of auditor's independence ethics and profesional skeptism on audit quality, Jurnal IImiah Mahasiswa FEB Universitas Brawijaya, 8(1).

[2] Arens, AA., Elder, RJ., Beasley, MS., \& Hogan, CE., (2017). Auditing and assurance services, Pearson.

[3] Badan Pemeriksa Keuangan Republik Indonesia, (2020). Laporan hasil pemeriksaan BPK atas laporan keuangan pemerintah pusat (LKPP) tahun 2019.
[4] Festinger, L., (1957). A theory of cognitive dissonance, Stanford university press.

[5] Gusti, M., \& Ali. S., (2008), Hubungan skeptisme profesional auditor dan situasi audit, etika, pengalaman serta keahlian audit dengan ketepatan pemberian opini auditor oleh akuntan publik, Simposium Nasional Akuntansi XI, Pontianak.

[6] Hermawan, A., \& Wulandari, R., (2019). Pengaruh pengalaman dan keahlian terhadap ketepatan pemberian opini audit melalui skeptisisme profesional auditor (Studi kasus pada kantor akuntan publik di Jakarta Selatan), Open Journl Unpam, 2(1).

[7] Institut Akuntan Publik Indonesia (IAPI) (2017). Standar profesional akuntan publik.

[8] Kamil, K., \& Fathonal, N., (2019). The effect of indepence, integrity, professionalism, and professional skeptism on the accuracy of giving an audit opinion, Advance in Economics, Business and Management Research, 127, 5-10.

[9] Keputusan Presiden Nomor 136 Tahun (1999). Tentang kedudukan, tugas, susunan organisasi dan tata kerja departemen.

[10] Komite Standar Akuntansi Pemerintah (KSAP) (2019). Standar akuntansi pemerintahan.

[11] Kushasyandita, R. S., \& Januarti, I. (2012). Pengaruh pengalaman, keahlian, situasi audit, etika dan gender terhadap ketepatan pemberian opini auditor melalui skeptisisme professional auditor (Studi kasus pada KAP big four di Jakarta). Jurnal Sistem Informasi, Etika Dan Auditing SNA XV.

[12] Lenz, R., \& Hahn, U. (2015). A synthesis of empirical internal audit effectiveness literature pointing to new research opportunities. Managerial Auditing Journal, 30(1), 5-33. doi:10.1108/maj-082014-1072

[13] Lubis, MES (2015). Pengaruh pengalaman auditor, kompetensi, risiko audit, etika, tekanan ketaatan, dan gender terhadap ketepatan pemberian opini auditor dengan skeptisme profesional auditor sebagai variabel intervening (Studi empiris pada kantor akuntan publik Pekanbaru dan kantor akuntan publik Medan), JOM FEKON, 2(1) 1-15.

[14] Nur DP, E., Julita, \& Wahyudi, D. P. (2014). Pengaruh etika, kompetensi, pengalaman auditor dan situasi audit terhadap ketepatan pemberian opini audit melalui pertimbangan materialitas dan skeptisisme profesional auditor. Jurnal IImiah STIE MDP, 3(2), 116-132.

[15] Pelu, M. F. A. (2018). Pengaruh skeptisme profesional auditor, situasi audit, etika profesi, pengalaman dan keahlian auditor terhadap ketepatan pemberian opini audit oleh akuntan publik. Jurnal IImiah Akuntansi Peradaban, 84, 487-492.

[16] Peraturan Badan Pemeriksa Keuangan Nomor 1 Tahun (2007). Tentang standar pemeriksaan keuangan negara (SPKN).

[17] Peraturan Badan Pemeriksa Keuangan Nomor 1 Tahun (2017). Tentang standar pemeriksaan keuangan negara (SPKN).

[18] Peraturan Inspektur Jenderal Nomor 115/PER-ITJEN/2020 Tentang pedoman pengawasan Inspektur Jenderal Kementerian Kelautan dan Perikanan.

[19] Peraturan Menteri Kelautan dan Perikanan Nomor 6/PERMEN$\mathrm{KP} / 2017$ Tentang organisasi dan tata kerja Kementerian Kelautan dan Perikanan.

[20] Peraturan Pemerintah Republik Indonesia Nomor 24 Tahun (2005). Tentang standar akuntansi pemerintahan (SAP).

[21] Peraturan Pemerintah Republik Indonesia Nomor 60 Tahun (2008). Tentang sistem pengendalian intern pemerintah (SPIP).

[22] Peraturan Pemerintah Republik Indonesia Nomor 71 Tahun (2010). Tentang standar akuntansi pemerintahan (SAP).

[23] Peraturan Pemerintah Republik Indonesia Nomor 18 Tahun (2016). Tentang perangkat daerah.

[24] Peraturan Pemerintah Republik Indonesia Nomor 72 tahun (2019). Tentang perangkat daerah.

[25] Robbins, S.P \& Judge, TA, (2015), Perilaku organisasi, Salemba Empat.

[26] Sari, A. R. (2017). Pengaruh independensi dan situasi audit terhadap ketepatan pemberian opini audit dengan fee audit sebagai variabel moderating (Studi kasus pada KAP di Jakarta Timur). Jurnal Akuntansi Manajerial, 2(4), 50-62.

[27] Sekretaris Jenderal BPK (1995) Standar audit Pemerintahan.

[28] Suraida, I. (2005). Pengaruh etika, kompetensi, pengalaman audit, dan risiko audit terhadap skeptisisme profesional auditor dan ketepatan pemberian opini akuntan publik, Journal of Social Sciences and Humanities, 7(3), 186-202.

[29] Suryani, L. (2017). Pengaruh skeptisme profesional, keahlian audit, lingkup audit, dan etika terhadap ketepatan pemberian opini auditor 
(Studi empiris pada BPK perwakilan Kepulauan Riau di Batam). Jurnal Online Mahasiswa FEKON, 4.

[30] Sutrisno, \& Fajarwati, D. (2014). Pengaruh pengalaman, keahlian, situasi audit, etika, dan gender terhadap ketepatan pemberian opini auditor melalui skeptisisme profesional auditor (Studi kasus pada KAP di Bekasi). Jurnal Riset Akuntansi Dan Keuangan, 5.

[31] The Institute of Internal Auditors (IIA) (2015). The IIA's international professional practices framework (IPPF).

[32] The Institute of Internal Auditors (2016). Standar internasional praktik profesional audit.

[33] Tuanakotta, TM., (2011). Berfikir kritis dalam auditing, Salemba empat.

[34] Tuanakotta, TM., (2017). Audit kontemporer, Salemba empat.

[35] Undang-undang Republik Indonesia Nomor 17 Tahun (2003). Tentang keuangan negara.

[36] Undang-undang Republik Indonesia Nomor 15 Tahun (2004). Tentang pemeriksaan pengelolaan dan tanggung jawab negara.

[37] Widiarini, KY., \& Saputra, IDGD., (2017). Pengaruh skeptisme profesional auditor, etika profesi, komitmen profesional auditor, dan keahlian audit terhadap pemberian opini, E-Jurnal Akuntansi Universitas Udayana, 18(1), 88-116.

[38] Winadi, N. G. A. R. A., \& Mertha, I. M. (2017). Pengaruh independensi, skeptisisme dan gender pada pertimbangan materialitas dan implikasinya pada ketepatan pemberian opini auditor. E-Jurnal Akuntansi, 19, 251-279.

[39] Wirasari, NNI., Sunarsih, NM., \& Dewi, NPS., (2019). Pengaruh skeptisisme profesional auditor, etika profesi, keahlian audit dan komitmen profesional auditor terhadap ketepatan pemberian opini oleh auditor pada kantor akuntan publik di Bali, Jurnal Riset Akuntansi (JUARA), 9(1), 109-123.

[40] Zakaria, A., Purwohedi, U., Memon, M., (2020). Internal audit competence and effectiveness: lesson from Indonesia, Palarch's Journal of Archaeology of Egypt/Egyptology 17(4), 192-200. 